\title{
Calibration Methods of Chlorine Analyzer
}

\author{
Long Wang ${ }^{1}$, Yufeng $\mathrm{Xu}^{2}$ \\ ${ }^{1}$ Chongqing Academy of Metrology and Quality Inspection, Chongqing 401123, China \\ ${ }^{2}$ Hebei University of Engineering, Handan 056038, China \\ cquwang@163.com, jackstarfly@sohu.com
}

Keywords: Chlorine analyzer. Calibration. Linear error. Repeatability.

\begin{abstract}
Chlorine analyzer is broadly used for determination of residual chlorine or total chlorine in water. It is very important to evaluate its performance and needed to be calibrated by metrology organizations. But there is no standard or regulation for chlorine analyzer calibration in our country. The calibration methods of chlorine analyzer was suggested on the basis of the function characteristics of the instrument for evaluating the metrological performance of the instruments.
\end{abstract}

\section{Introduction}

Chlorine analyzer is broadly used in food and drink, medical and health, running water supply, culture industry and other industries for determination of residual chlorine or total chlorine in water whether it met the water quality standard. There is no standard or regulation for chlorine analyzer calibration in our country. The calibration can be done only depending on the work experience of calibration staff or referring the instructions of instrument. Therefore, chlorine analyzer must be calibrated regularly to ensure it's accuracy and reliability of test results. Now, referring to the corresponding industry standards and the performance of chlorine analyzer, the calibration methods of chlorine analyzer was suggested and tested.

\section{Working principle}

The main principle of chlorine analyzer is spectrophotometry (DPD). Residual chlorine or total chlorine in water reacts with DPD reagents and becomes light red. The absolute value of the water sample is proportional to the chlorine concentration, so the concentration of residual chlorine or total chlorine in water can be quantitative analysised [1].

\section{Calibration Items}

There is no available chlorine reference material up to now, so the cobalt chloride standard solution used in "Semiautomatic Clinical Chemistry Analyzers" ( JJG 464-2011) was used in the test to calibrate the overall metrological performance of chlorine analyzer [2]. Referring to the instructions of instrument and the analysis methods in national standard, the calibration items such as zero drift, linear error, and repeatability was validated[3]. 


\section{Zero Drift}

The Class A water defined in "Water for analytical laboratory use-Specification and test methods" (GB/T 6682-2008) was filled in sample cell of chlorine analyzers [4]. The detection was repeated every ten minutes within an hour and the zero drift of these chlorine analyzers were all below \pm 1.0 $\%$ FS. Accordingly, the limit value of zero drift was determined to be $\pm 1.0 \% \mathrm{FS}$.

\section{Linear Error}

There will be certain errors exist in the course of test, such as the error of instrument itself, and the uncertainty of measurement of standard substance. In the test, three or five cobalt chloride standard solution of concentration gradient distribute equably in the measuring range of the instrument were tested with chlorine analyzers of three types and specifications and the results were showed in Table 1 . Then the maximum allowable linear error of chlorine analyzer were determined as below $\pm 5 \%$.

Table 1. Linear error of chlorine analyzers

\begin{tabular}{|c|c|c|c|c|c|}
\hline $\begin{array}{c}\text { Type } \\
\text { specification }\end{array}$ & Manufacturer & $\begin{array}{c}\text { Reference } \\
\text { material } \\
\text { concentration }(\mathrm{g} / \mathrm{L})\end{array}$ & $\begin{array}{l}\text { Mean } \\
\text { response } \\
\text { value }\end{array}$ & Error $(\%)$ & $\begin{array}{c}\text { Linear } \\
\text { error }(\%)\end{array}$ \\
\hline \multirow[t]{5}{*}{ C401 } & \multirow{5}{*}{$\begin{array}{l}\text { INSTRUMENTS } \\
\text { Company }\end{array}$} & 2.0 & 0.50 & -0.4 & \multirow{5}{*}{+3.6} \\
\hline & & 4.0 & 1.00 & -0.4 & \\
\hline & & 6.0 & 1.49 & -1.2 & \\
\hline & & 8.0 & 1.99 & -0.8 & \\
\hline & & 10.0 & 2.60 & +3.6 & \\
\hline \multirow{3}{*}{$\begin{array}{c}\text { Pocket } \\
\text { Colorimeter }\end{array}$} & \multirow{3}{*}{$\begin{array}{c}\text { HACH Company } \\
\text { (U.S.A. ) }\end{array}$} & 2.0 & 1.43 & -2.7 & \multirow{3}{*}{+3.4} \\
\hline & & 4.0 & 2.92 & -0.7 & \\
\hline & & 6.0 & 4.56 & +3.4 & \\
\hline \multirow{2}{*}{$\begin{array}{c}\text { Pocket } \\
\text { Colorimeter }\end{array}$} & \multirow{3}{*}{$\begin{array}{c}\text { HACH Company } \\
\text { (U.S.A. ) }\end{array}$} & 2.0 & 1.36 & -1.6 & \multirow{3}{*}{-1.6} \\
\hline & & 4.0 & 2.77 & +0.1 & \\
\hline II & & 6.0 & 4.20 & +1.3 & \\
\hline
\end{tabular}

\section{Repeatability}

The appropriate concentration of cobalt chloride standard solution was detected referring to the instructions of chlorine analyzer. The detection was repeated 6 times and the results were showed in Table 2. Combining with the instrument technical index of various manufacturers, the repeatability limit value of chlorine analyzers were determined below $1.0 \%$. 
Table 2. Repeatability of chlorine analyzers

\begin{tabular}{cccc}
\hline $\begin{array}{c}\text { Type } \\
\text { specification }\end{array}$ & Manufacturer & $\begin{array}{c}\text { Mean response } \\
\text { value }\end{array}$ & $\begin{array}{c}\text { Repeatability } \\
(\%)\end{array}$ \\
\hline C401 & $\begin{array}{c}\text { INSTRUMENTS } \\
\text { Company (Singapore) }\end{array}$ & 1.99 & 0.2 \\
\hline Pocket & HACH Company & 1.43 & 0.0 \\
Colorimeter II & (U.S.A.) & & 0.2 \\
\hline $\begin{array}{c}\text { Pocket } \\
\text { Colorimeter }\end{array}$ & HACH Company & 2.78 & \\
\hline
\end{tabular}

\section{Discussions}

According to the working principle of chloride analyzer, the metrological characteristics of the instrument can not be evaluated accurately and comprehensively without the indication error. In the test, only linear error of chloride analyzer can be obtained with standard solution of concentration gradient. Thus, indication error of the instrument unable to be obtained because of the chlorine concentration can not be transformed from cobalt chloride standard solution concentration. Therefore, the indication error of chloride concentration should to be further studied on the basis of the preliminary study on other function characteristics such as zero drift, linear error, and repeatability.

\section{Acknowledgements}

This work was financially supported by the Research Planning Project of General Administration of Quality Supervision, Inspection and Quarantine of the People's Republic of China (2013Qk005).

\section{References}

[1] LI Meng-yao, et al. Recent Advances of Determination of Residual Chlorine in Water [J]. Environmental Monitoring in China, 2007, 23(2): 40-42.

[2] JJG 464-2011. Semiautomatic Clinical Chemistry Analyzers [M]. Beijing: China Metrology Publishing House, 2011.

[3] JJF 1001-2011. General Terms in Metrology and Their Definitions [M]. Beijing: China Metrology Publishing House, 2011.

[4] GB/T 6682-2008. Water for analytical laboratory use-Specification and test methods [S]. Beijing: Standards Press of China, 2008. 